\title{
The Usage of Diminutives by Children in Polish as the Example of Imitating Mother's Speech
}

\author{
Paulina Biały \\ Uniwersytet Śląski \\ bialypaulina@gmail.coml
}

\begin{abstract}
The aim of this paper is a review of most common situations in which children use diminutive forms in Polish, excluding the reference to the smallness of an object being pointed at, illustrated with the examples of the usage of diminutives, collected by the author of this paper. The examples are taken from everyday conversations of children aged 2-10. It is claimed that children imitate adult speech and borrow certain features, such as the usage of diminutive forms, as they shape their language mainly following the example of relatives. As the review shows, children use diminutives in various contexts, from establishing emotional contact with other children or their toys, familiarizing themselves with the reality and everyday life, or diminishing their fault to even flattering or buttering up the hearer.
\end{abstract}

Keywords: diminutives, child's speech, familial language.

\section{Streszczenie}

Użycie zdrobnień przez polskie dzieci jako przykład naśladowania mowy matki

Artykut stanowi przegląd najbardziej powszechnych kontekstów użycia $w$ języku polskim zdrobnień przez małe dzieci, z wytaczeniem odniesień związanych z matym rozmiarem danego przedmiotu. Ilustrowany jest przykładami użycia tych form, zebranymi przez autorke artykułu, a zaczerpniętymi z codziennych rozmów dzieci w wieku od dwóch do dziesięciu lat. Uważa się, $\dot{z} e$ dzieci imituja mowe dorostych oraz zapożyczaja od nich pewne cechy, kształtujac $w$ ten sposób swój własny język. Przegląd pokazuje, iz dzieci używaja zdrobnień $w$ różnorodnych kontekstach, począwszy od nawiazywania kontaktu emocjonalnego z innymi dziećmi czy swoimi zabawkami, oswajania się z otaczająca ich rzeczywistościa $i$ życiem codziennym, czy też umniejszania swoich przewinień, aż do schlebiania swojemu rozmówcy.

Słowa kluczowe: zdrobnienia, mowa dziecka, język rodzinny 


\section{Introduction}

In the prototypical domain, diminutive use is a feature of adult speech rather than of children's speech $^{11}$. The use of diminutives is based on adult preconceptions of language input adequate for children, then children start imitating caretaker speech. Zgółkowa (1991: 47) is of the opinion that children use diminutives very frequently ${ }^{2}{ }^{2}$ Zarębina (1965: 58, 1980: 111) as well emphasizes that children's speech is full of diminutives, both adopted from adult speech and created on their own. Some diminutives occur in child's speech more frequently than their base forms (Zgółkowa, 1990: 17-31), e.g. gwiazdka (star-DIM.), kotek (cat-DIM.), literka (letterDIM.), muszelka (shell-DIM.), wierszyk (poem-DIM.), zajaczek (hare-DIM.), żabka (frogDIM.). Gąsiorek (1994: 26) mentions also the fact that diminutive forms of first names occur most often in children's language. Moreover, almost in all cases, children use the diminutive form of the first name while talking to or referring to other children (Zgółkowa, 1990: 31-33). Dąbrowska (2006: 131) adds that, in languages such as Polish, "the use of diminutive affixes helps to make gender or some other important morphological distinction more transparent", that is why children use diminutives so willingly.

The paper is aimed at reviewing most common situations in which children use diminutive forms, excluding the reference to the smallness of an object being pointed at. The examples of the usage of diminutives, collected by the author of this paper, are taken from everyday conversations of children aged 2-10. The applied data collection method was participant observation. The following group of ten children was observed:

- $\quad$ two girls at the age of 2;

- $\quad$ seven children at the age of 6 (one girl and six boys);

- $\quad$ one boy at the age of 10 .

The observation was undertaken in the spring of 2016 during several meetings of the author's children with their friends. The meetings took place once a week mostly at home, but also at the zoo or at the playground. Apart from the author of this paper, the parents or grandparents of other children were also present.

\footnotetext{
${ }^{1}$ For more information concerning the usage of diminutive forms see Biały, 2017.

2 Zgółkowa and Bułczyńska (1987: 325-337) list ten most frequent diminutives (apart from diminutive forms of first names) used by Polish children aged 3-7: mamusia (mummy), tatuś (daddy), kotek (cat-DIM.), piesek (dogDIM.), domek (house-DIM.), malutki (small-DIM.), zajączek (hare-DIM.), ptaszek (bird-DIM.), rybka (fish-DIM.), pszczótka (bee-DIM.).
} 


\section{Diminutives in conversations with a small child}

According to Grabias (1988: 39-40) and Handke (1992: 154-155), when talking to children women seem to use diminutives more often than men as they are more emotional and sensitive (see also Biały, 2017: 72; Bartmiński, 2009: 154, 157-158; Brzozowska, 2000: 87; Handke, 2008: 168). As Pikor-Niedziałek (2007: 84) states, women's language is the language of intimacy and bonds, while men's language is the language of status and independence. Following Engle, Pikor-Niedziałek (2007: 91) adds that when playing with children, fathers are more directive in their speech than mothers, because mothers view interaction as an occasion to help children, while fathers are less concerned with the children's desires and introduce new ideas. Holmes (1995: 2) also underlines the fact that men focus on the content of the talk and its outcome, while women focus on how the talk affects the feelings of others. Mandal, Gawor and Buczny (2012: 13) present the female trait stereotype which includes:

- emotionality,

- ability to make sacrifices,

- gentleness,

- sensitivity,

- caring for others' feelings,

- the ability to understand others,

- warmth in relations with others,

- helping.

Thus, the stereotypical female roles are as follows:

- giving emotional support to others,

- managing the household,

- taking care of the children,

- responsibility for arranging the household.

They also list some stereotypical male traits (Mandal, Gawor and Buczny, 2012: 13):

- independence,

- being active,

- competence,

- decisiveness,

- reliability,

- self-confidence,

- not yielding to pressure, 
- $\quad$ sense of leadership.

Thus, the stereotypical male roles are as follows:

- being the head of the household,

- providing financially for the family,

- leadership,

- responsibility for household repairs.

Men and women differ as well when it comes to language use. Following Gal, Weatherall (2002: 54) points out that male-female differences in speech occur in numerous parts of the linguistic system, such as phonology, pragmatics, syntax, morphology, or lexicon. Following Lakoff, Eckert and McConnell-Ginet (2003: 158) distinguish between “women's language” and "men's language". They mention the use of diminutives among devices aimed at softening and attenuating women's expression of opinion (see also Handke, 2008: 163-166).

It is also worth noticing that women seem to use diminutive forms more often than children, as non-adults are not fully aware of all their connotations. Besides, it is a child who is treated as somebody who is weak and defenseless. Znaniecki (2011: 161) believes that a mother is supposed to initiate a long-lasting social relation with her child. In his opinion, her duty is to guarantee that the child evaluates her positively, and make him/her aware that he/she is positively evaluated by her (Znaniecki, 2011: 161). Moreover, as the newborn infant is not conscious of her or of him/herself, the mother must help him/her acquire such consciousness. This may be done by using diminutives in mother's speech (e.g. when praising it), as normally mothers begin to speak to their children very early.

Wojtczuk (2001: 181), following Jurkowski, describes the language of women when talking to small children as nannies' language (język nianiek). It is an element of familial language which vanishes as the child grows up. Handke (2008: 130-131) calls it the language of love and tenderness (język miłości i czułości). The use of diminutives and hypocorisms in this particular context seems to be most obvious and natural (Dunaj, Przybylska, and Sikora, 1999: 236; Lubecka, 1993: 100). Gawroński (1928: 210) claims that the mood of adults keeping company with a child is reflected in their speech through the use of diminutives. It is caused by the fact that adults unintentionally express their affection for the child's trust and helplessness.

Following Kita (1993: 106), Biały (2017: 73-74) stresses the fact that "the use of diminutives when referring to children is not limited to the area of family, but may be applied in other contexts as well (e.g. in television programmes intended for young viewers)".

Moreover, basing on Kaczorowska's view (1993: 74-75), she claims that "even though diminutives are used by adults to communicate positive emotions and affection, these forms 
reflect the asymmetry of the adult-child constellation, therefore, at some age children start protesting when they hear diminutives. Moreover, as the child grows up, he/she gradually stops using diminutives in his/her speech (Biały, 2017: 74).

\section{The core of the matter - imitating the adults}

Zgółkowa (1986: 20) states that people from the child's closest circle have significant influence on shaping his/her language. For adults, a child is a miniature of a person. Therefore, they believe that everything should be miniaturised for him/her by using diminutives in their speech (Zgółkowa, 1986: 39-40). The child shapes his/her language mainly following the example of relatives. Thus, he/she imitates adult speech and borrows certain features. Therefore, if relatives use a lot of diminutives in their conversations with a child, he/she will also like using them in his/her language, e.g. when talking to dolls or teddy bears, referring to him/herself, talking to other people/children, or referring to animals/plants (Zgółkowa, 1986: 74). As Kaczmarek (1953: 4-5, 25) states, the bigger the adults' emotional attitude towards the child is, the more diminutives the child uses in his/her speech.

As mentioned above, women are considered more emotional than men and it is them who inspire children to use diminutives and other expressive linguistic forms in their speech. According to Biały (2017: 72), "by using diminutive forms, adults want to give a child a sense of security and certainty that he/she is loved by them. By this, they want the child to know that he/she is of special importance for them (see Dobrzyński, 1988: 113). Therefore, using diminutives is a good way to establish emotional contact with the child". It is imitated in child's speech while:

$\checkmark$ talking to dolls or teddy bears:

(1) Ty mój skarbeczku! (My sweetheart-DIM.DIM.!)

(2) Mamusia zaraz da obiadek. (Mummy will give you dinner-DIM. right away.)

$\checkmark$ referring to him/herself:

(3) Wituś jest grzecznym chłopczykiem. (Witold-DIM.DIM. is a good boy-DIM.)

(4) Ja bardzo lubię chlebek z masetkiem i szyneczka. (I like bread-DIM. with butter-DIM. and ham-DIM. very much).

$\checkmark$ talking to other people:

(5) Tatuś zrobi sosik z cebulka. (Daddy will make some sauce-DIM. with onion-DIM.)

(6) Mamusia pierze moje majteczki. (Mummy is washing my shorts-DIM.)

(7) Babciu, będziesz pić kawkę? (Are you going to drink coffee-DIM., grandma?) 
Adults use diminutives to refer to objects belonging to or made by a child, and to refer to the child's appearance or body parts (Biały, 2017: 73). Consequently, the child also uses diminutive forms, e.g. książeczka (book-DIM.), rączki (hands-DIM.).

It is worth mentioning that Dressler and Barbaresi (1994: 191-193) notice that diminutives can be used not only when referring to people, but also when talking to small animals, as "pets are treated like small children and therefore they can also be addressed like small children". Then, this particular use of diminutives represents a metaphorical extension of 'diminutivum puerile'. Adults use diminutives to refer to animals. A child imitates this, e.g.: myszki (miceDIM.), zwierzatko (animal-DIM.), maty kotek z biata mordka (little cat-DIM. with white muzzle).

Adults use diminutive forms to refer to young people as well. A child may follow it by referring to other children, e.g.: mały chłopczyk (little boy-DIM.), Kacperek (Casper-DIM.), Sebuś (Sebastian-DIM.DIM.).

Biały (2017: 73) claims that "diminutives express our care, as we want to soften the world we live in, so that it would not seem so menacing and strange for the child. We tend to prove to the child that the world is friendly and "full of nice creatures and pleasant events" (Wierzbicka, 1990: 79). As Gałczyńska (2006: 90) writes, by naming different things and ideas, we want to familiarize the child with the reality and everyday life". It is also imitated in child's speech:

(8) O, stonik taki duży. (Wow, such a big elephant-DIM.)

(9) Popatrz, jak deszczyk pada. (Just look at the rain-DIM.)

Adults use diminutives to soften commands and requests (Jurafsky, 1996: 558; Biały, 2017: 155), which is imitated by a child while talking to other children:

(10) Daj mi tamta książeczkę. (Give me that book-DIM. over there.)

(11) Chodź szybciutko! (Come quickly-DIM.!)

Adults use diminutives to offer food or drink (Wierzbicka, 1984: 128; Biały, 2017: 157). A child imitates this while talking to toys or other children:

(12) Chcesz jeszcze herbatki? (Do you want some more tea-DIM.?)

A child may imitate adults who use diminutives to express content (Biały, 2017: 160), e.g. pyszne pierniczki (delicious gingerbread cakes-DIM.), dobry obiadek (good dinner-DIM.).

Adults use diminutives to express sympathy and care (Biały, 2017: 123). A child imitates not only the linguistic form but also the intonation:

(13) Główka cię boli? (Is your head-DIM. aching?)

(14) Rekin zjadt tę mata rybkę! (The shark has eaten this little fish-DIM.!) 
Adults use diminutives to intensify the meaning (Biały, 2017: 110). A child, rather unconsciously, does the same:

(15) maleńki paluszek (tiny finger-DIM.)

(16) Mam petniutki brzuszek. (My tummy is full-DIM.)

\section{Other contexts of using diminutives in child's speech}

As the child grows, he/she becomes more aware of the possible contexts of using diminutives. Sifianou (1992: 158) notices that children make extensive use of diminutives, both when repeating what they have heard and when attempting to sound nice or less demanding in order to obtain adults' agreement or compliance. In some cases, when the child does something wrong, he/she may want to diminish his/her fault:

(17) Mamusiu, to ja wylatem herbatke. (Mummy, it was me who spilt the tea-DIM.)

Sometimes the child uses diminutive forms in order to flatter or butter up the hearer (Biały, 2017: 160):

(18) Dziadziusiu, jaka piękna choineczka! (What a beautiful Christmas tree-DIM., grandfatherDIM.!)

It is also common for the child to use diminutives to express affection (Biały, 2017: 117): (19) Kocham moją mamusię. (I love my mummy.)

\section{Conclusion}

The usage of diminutives by adults plays significant role in familiarizing children with the reality they live in. At first, children imitate the adult speech and, after they acquire enough linguistic data, start using diminutives in a more productive way. As the review presents, the most common contexts of using diminutives in child's speech are as follows:

a) while referring to particular designata:

- to talk to dolls or teddy bears; refer to him/herself; talk to other people/children, refer to animals/plants (Zgółkowa, 1986: 74; Dressler and Barbaresi, 1994: 191-193);

- to refer to objects belonging to or made by a particular child, and to refer to the child's appearance/body parts (Zgółkowa, 1986: 39-40);

- to establish emotional contact with other children or child's toys (Dobrzyński, 1988: 113); 
- to familiarize oneself with the reality and everyday life (Wierzbicka, 1990: 79; Gałczyńska, 2006: 90);

b) while applying them in particular speech acts:

- to soften commands and requests (Jurafsky, 1996: 558; Biały, 2017: 155);

- $\quad$ to offer food or drink (Wierzbicka, 1984: 128; Biały, 2017: 157);

- to diminish one's fault (Sifianou, 1992: 158);

- to flatter or butter up the hearer (Biały, 2017: 160);

c) while expressing particular meanings:

- to express content (Biały, 2017: 160);

- to express sympathy and care (Biały, 2017: 123);

- $\quad$ to express affection (Biały, 2017: 117);

- $\quad$ to intensify the meaning (Biały, 2017: 110).

It might be concluded that the children's world is full of emotive meanings of diminutives, even though they may not be fully aware of all their connotations.

\section{References}

Bartmiński, Jerzy (2009) Językowe podstawy obrazu świata. Lublin: Wydawnictwo UMCS. Biały, Paulina (2017) Polish and English Diminutives in Literary Translation: Pragmatic and Cross-cultural Perspectives. Katowice: Wydawnictwo Uniwersytetu Śląskiego.

Brzozowska, Dorota (2000) O dowcipach polskich i angielskich. Aspekty językowo-kulturowe. Opole: Wydawnictwo Uniwersytetu Opolskiego.

Dąbrowska, Ewa (2006) "Low-level Schemas or General Rules? The Role of Diminutives in the Acquisition of Polish Case Inflections." Language Sciences. 28(1); 120-135.

Dobrzyński, Walenty (1988) Z badań nad rozwojem polskich deminutywów. Wrocław: Wydawnictwo Naukowe PWN.

Dressler, Wolfgang U., Lavinia M. Barbaresi (1994) Morphopragmatics. Diminutives and Intensifiers in Italian, German, and Other Languages. Berlin, New York: Mouton de Gruyter.

Dunaj, Bogusław, Renata Przybylska, Kazimierz Sikora (1999) "Język na co dzień.” [In:] Walery Pisarek (ed.) Polszczyzna 2000. Orędzie o stanie języka na przełomie tysiacleci. Kraków: Wydawnictwo Uniwersytetu Jagiellońskiego; 227-251.

Eckert, Penelope, Sally Mc-Connell-Ginet (2003) Language and Gender. Cambridge: Cambridge University Press. 
Gałczyńska, Alicja (2006) "Oswajanie codzienności. Sposoby mówienia przez dorosłych do niemowląt i noworodków.” [In:] Małgorzata Marcjanik (ed.) Retoryka codzienności. Zwyczaje językowe współczesnych Polaków. Warszawa: Wydawnictwo Trio; 89-97.

Gawroński, Andrzej (1928) "Wartość uczuciowa deminutywów." [In:] Andrzej Gawroński Szkice językoznawcze. Kraków: Gebethner i Wolff; 199-217.

Gąsiorek, Krystyna (1994) "Deminutywa najczęstsze i najrzadsze w języku pisanym klasy trzeciej." [In:] Maciej Kawka (ed.) Ze studiów nad językiem dziecka i literatura dziecięca. Kraków: Wydawnictwo Naukowe WSP; 23-28.

Grabias, Stanisław (1988) "Socjolingwistyczne perspektywy badań nad ekspresywnością języka." Socjolingwistyka. 8(1); 35-43.

Handke, Kwiryna (1992) "Status rodzinny i zawodowy a językowe zachowania kobiet i mężczyzn.” Rocznik Naukowo-Dydaktyczny WSP w Krakowie. 152(1); 151-160.

Handke, Kwiryna (2008) Socjologia języka. Warszawa: Wydawnictwo Naukowe PWN.

Holmes, Janet (1995) Women, Men and Politeness. London: Longman.

Jurafsky, Daniel (1996) "Universal Tendencies in the Semantics of Diminutives." Language. 72(3); 533-578.

Kaczmarek, Leon (1953) Ksztattowanie się mowy dziecka. Poznań: Poznańskie Towarzystwo Przyjaciół Nauk.

Kaczorowska, H. (1993) "O zaniku zdrobnień w wypowiedziach lekcyjnych.” [In:] Edward Polański, Zenon Uryga (eds.) Z teorii i praktyki dydaktycznej języka polskiego. Katowice: Wydawnictwo Uniwersytetu Śląskiego; 74-81.

Kita, Małgorzata (1993) "Odmiany językowe w telewizyjnych programach dla dzieci i młodzieży.” [In:] Edward Polański, Zenon Uryga (eds.) Z teorii i praktyki dydaktycznej języka polskiego. Katowice: Wydawnictwo Uniwersytetu Śląskiego; 96-109.

Lubecka, Anna (1993) Forms of Address in English, French and Polish: A Sociolinguistic Approach. Kraków: Wydawnictwo Uniwersytetu Jagiellońskiego.

Łobos, Anna (2003) Język czasopism i programów telewizyjnych dla dzieci. Katowice: Wydawnictwo Uniwersytetu Śląskiego.

Mandal, Eugenia, Agnieszka Gawor, Jacek Buczny (2012) "The Stereotypes of Man and Woman in Poland - Content and Factor Structures.” [In:] Eugenia Mandal (ed.) Masculinity and Femininity in Everyday Life. Katowice: Wydawnictwo Uniwersytetu Śląskiego; 11-32.

Pikor-Niedziałek, Marta (2007) Linguistic Politeness versus Impoliteness. The Study of Press Interviews. Rzeszów: Wydawnictwo Uniwersytetu Rzeszowskiego. 
Sifianou, Maria (1992) "The Use of Diminutives in Expressing Politeness: Modern Greek versus English.” Journal of Pragmatics. 17(1); 155-173.

Weatherall, Ann (2002) Gender, Language and Discourse. New York: Routledge.

Wierzbicka, Anna (1984) "Diminutives and Depreciatives: Semantic Representation for Derivational Categories." Quaderni di Semantica. 5(1); 123-130.

Wierzbicka, Anna (1990) "Podwójne życie człowieka dwujęzycznego." [In:] Władysław Miodunka (ed.) Język polski w świecie. Warszawa: Wydawnictwo Naukowe PWN; 71 104.

Wojtczuk, Krystyna (2001) "'"Mówienie do dzieci” jako kategoria komunikacyjna.” [In:] Grażyna Habrajska (ed.) Język w komunikacji III. Łódź: Wydawnictwo Wyższej Szkoły Humanistyczno-Ekonomicznej w Łodzi; 179-186.

Zarębina, Maria (1965) Kształtowanie się systemu językowego dziecka. Wrocław, Kraków: Wydawnictwo Państwowej Akademii Nauk.

Zarębina, Maria (1980) Język polski w rozwoju jednostki: Analiza tekstów dzieci do wieku szkolnego. Rozwój semantyczny języka dziecka. Kraków: Wydawnictwo Naukowe WSP.

Zgółkowa, Halina (1986) Czym język za młodu nasiąknie... Poznań: Wydawnictwo Poznańskie. Zgółkowa, Halina, Katarzyna Bułczyńska. (1987) Słownictwo dzieci w wieku przedszkolnym: listy frekwencyjne. Poznań: Wydawnictwo UAM.

Zgółkowa, Halina (1990) Świat w dziecięcych słowach. Poznań: Wydawnictwo Poznańskie.

Zgółkowa, Halina (1991) "Leksyka ekspresywna jako wyróżnik potocznej odmiany współczesnej polszczyzny.” [In:] Stanisław Gajda, Zbigniew Adamiszyn (eds.) Język potoczny jako przedmiot badań językoznawczych. Opole: Wydawnictwo Wyższej Szkoły Pedagogicznej im. Powstańców Śląskich w Opolu; 45-52.

Znaniecki, Florian (2011) Relacje społeczne i role społeczne. Niedokończona socjologia systematyczna. Warszawa: Wydawnictwo Naukowe PWN. 